\title{
Molecular Insight in the Multifunctional Effects of Oridonin
}

\author{
Brice Ayissi Owona $^{1} \cdot$ Herman J. Schluesener $^{1}$
}

Published online: 20 August 2015

(C) The Author(s) 2015. This article is published with open access at Springerlink.com

\begin{abstract}
Oridonin has attracted considerable attention in the last decade because of its anti-cancer pharmacological properties. This ent-kaurane diterpenoid, isolated from the Chinese herb Rabdosia rubescens and some related species, has demonstrated great potential in the treatment profile of many diseases by exerting anti-tumor, anti-inflammatory, pro-apoptotic, and neurological effects. Unfortunately, the mechanisms via which oridonin exerts these effects remain poorly understood. This review provides an overview of the multifunctional effects of oridonin as well as the reasons for its potential for investigations in the treatment of many diseases other than cancer.
\end{abstract}

\section{Key points}

Oridonin has attracted considerable attention in the last decade because of its effects against cancer.

Several molecular targets of Oridonin have been identified, suggesting that oridonin may be effective in the treatment of many other disorders in addition to cancer (Alzheimer disease, inflammation, immunomodulation).

Due to its multitarget activity, oridonin has potential to be a promising compound for future drug development.

Brice Ayissi Owona

briceayissi03@yahoo.fr

1 Division of Immunopathology of the Nervous System, Institute of Pathology and Neuropathology, University of Tübingen, Calwer Street 3, Tübingen, Germany

\section{Introduction}

Oridonin is a famous diterpenoid isolated from the Chinese medicinal herb Rabdosia rubescens, also known as dong ling cao (Fig. 1). This member of the Lamiaceae family is widely distributed in China and Japan. It is traditionally used in Chinese medicine as an anti-tumor, anti-microbial, anti-inflammatory, and anti-oxidant compound [1,2]. It is also used as a supplement in the treatment of many cancers, such as esophagus, mammary gland, liver, and prostate cancers and has even been a folk remedy for carcinomas of the heart and esophagus in Hunan province [3]. Oridonin was identified for the first time in 1967 and synthesized in 1973 [4]. It is currently one of the most important compounds isolated from traditional Chinese herbal medicines [5]. Indeed, oridonin is an ent-kaurane diterpene that has been shown to have multiple biological activities. Among them, the anti-cancer activity, which is reported to occur through different cellular signaling pathways, has been repeatedly reported. For instance, the chemopreventive and anti-tumor effects of oridonin have been related to its ability to interfere with several pathways involved in cell proliferation, cell cycle arrest, and apoptosis [6].

To characterize the bioactive compounds in Rabdosia, oridonin was first isolated from the plant Isodon japonicus (Burm. f.) H. Hara, the common name of which in Japanese is orido, hence the chemical name [7]. The compound has drawn attention for its remarkable apoptosis and autophagy-inducing activity in cancer therapy. However, the results of many prominent studies have proven that oridonin possesses many other therapeutic effects, such as anti-inflammatory, neuroprotective, anti-bacterial, and anti-neoplastic effects [7, 8]. For instance, oridonin attenuates $\beta$-amyloid deposition, plaque-associated amyloid precursor protein (APP) 
expression, and microglial activation in the brain of transgenic mice [9]. These observations reveal the promising therapeutic effects of oridonin, suggesting that it may be a potent alternative drug for human neurodegenerative and other inflammation-related diseases. Oridonin could also induce apoptosis through the generation of reactive oxygen species (ROS) in human hepatoma HepG2 cells [10]. Moreover, it has been suggested that oridonin is able to inactivate many signaling pathways such as protein kinase B (Akt) and ERK and activate p38 mitogen-activated protein kinase (MAPK) and c-Jun $\mathrm{N}$-terminal kinase (JNK) signaling pathways [11, 12]. Oridonin can also trigger cell cycle arrest, apoptosis, and autophagy in different neoplastic cell lines [13]. Despite the large number of studies reporting the therapeutic effects of this diterpene, the entire molecular mechanism underlying its multi-targeted effects remains to be elucidated. This review summarizes the considerable knowledge about the action mechanisms of oridonin, which has been studied in recent years. We also focus on highlighting the updated data related to multi-functional effects of oridonin in many diseases, as well as its potential application in preclinical trials.

\section{Oridonin: Isolation and Structure}

Oridonin is a diterpenoid (Fig. 1) isolated from the traditional Chinese herb Rabdosia rubescens. However, many reports also mention the isolation of oridonin from other plants and

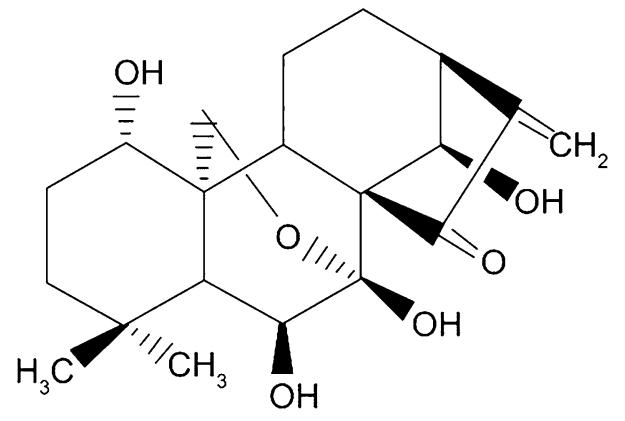

Fig. 1 Structure of oridonin from different countries (e.g. Isodon japonica leaves) (Table 1). Oridonin has been reported in 12 of 74 species of isodon, and phylogeny results indicate that its production has arisen at least three times in the genus [14]. The production source and harvesting region have an important impact on the quality and quantity of oridonin produced. Therefore, Isodon rubescens or Isodon japonicus from Hunan province are considered to provide the best source of oridonin $[14,15]$.

\section{Molecular Targets of Oridonin}

Interest is increasing in the study of oridonin activities and its potential effect in the treatment of many diseases [16]. Several of these studies have reported anti-proliferative, anti-inflammatory, and anti-neoplastic effects as well as effects on the immune system $[17,18]$. The exact mechanisms by which oridonin exerts these activities are not well understood. Several proteins and receptors with which oridonin can directly or indirectly interact have been reported. Among the targets of oridonin, proteases, transcription factors, and kinases have been characterized, and the most important of them are discussed in this review.

\subsection{Structural Proteins Targeted by Oridonin}

Oridonin is reported to act on different cellular targets. The compound regulates the protein expression of MAP-LC3 and Beclin 1 in HeLa cells [19]. Oridonin was also reported to regulate p53 and p21 protein expressions in oridonintreated MCF-7 human breast cancer cells [20]. The molecular chaperone heat shock protein (HSP)-70 1A was identified as an oridonin target in Jurkat cells, where HSP70 inhibition by oridonin might result in the impairment of some client proteins, thus in turn affecting several molecular pathways [6]. The expression of the anti-apoptotic protein BCL-2 was reported to decrease in apoptotic MCF-7 breast cancer cells treated with an oridonin nanosuspension [21]. Experimental data showed that oridonin significantly reduced c-Myc protein levels in vitro

Table 1 Isolation of oridonin from different plant sources

\begin{tabular}{|c|c|c|c|}
\hline Plant source & Part of the plant & Compounds isolated & References \\
\hline Rabdosia rubescens & Leaves & 16, 17-exo-epoxide oridonin and 11,15-0,0-diacetylrabdoternins & [94] \\
\hline Rabdosia nervosa & Stem and leaves & Lasiakaurin, ponicidin, oridonin & {$[99]$} \\
\hline Rabdosia japonica (Labiatae) & Aerial part & Oridonin, nodosin & {$[95,100]$} \\
\hline Isodon japonica & Leaves & Epinodosin, oridonin, epinodosinol, lasiokaurin, rabdoternin A & {$[101]$} \\
\hline Isodon rubescens & Leaves & Oridonin, ponicidin, lasiokaurin, enmenol & {$[101,102]$} \\
\hline Isodon serra & Leaves & Oridonin, lasiodonin & {$[55]$} \\
\hline Isodon leucophyllus & Aerial parts & Macrocalin B, oridonin, rosthorin, rabdoternin A & {$[103]$} \\
\hline Tibetan medicine Caryoteris toroetii & - & Oridonin, nodosin & [104] \\
\hline
\end{tabular}


and in vivo and that this reduction was mediated by the ubiquitin-proteasome system [22]. The compound was also reported to increase the ratio of $\mathrm{BAX} / \mathrm{BCL}-2$ protein expression in murine L929 cells [23]. A downregulation of the levels of Mcl-1 and BCL-x(L) cells, but not of Bcl-2 protein, was observed in both MT-1 and RPMI8226, which are adult T-cell leukemia and multiple myeloma cells, respectively [24]. The downregulation of activator protein (AP)-1 gene expression is considered to be an initial event in the oridonin-mediated inhibition of colorectal cancer, and AP-1 downregulation is also considered to be the initial response to treatment with oridonin [25]. Oridonin treatment downregulated the expression of the inhibitor of apoptosis protein (IAP) in osteosarcoma cells, and also induced the release of cytochrome $\mathrm{c}$ accompanied by activation of caspase-9, caspase-3, and cleavage of poly (ADP-ribose) polymerase (PARP) [26]. Oridonin induced apoptosis in A431 cells via an upregulation of the ratio of mitochondrial proteins, BAX/BCL-2 (Table 2). In addition, the total tyrosine kinase activity of cellular mitochondrial proteins and expression of epidermal growth factor receptor (EGFR) were markedly reduced after oridonin treatment [27]. The changes in BCL-2 and BAX protein levels play an important role in the mechanism of action of oridonin [5]. Oridonin has significant anti-proliferation effects on HPB-ALL cells via induction of apoptosis as well as directly causing cell necrosis by activation of caspase 3 as well as downregulation of antiapoptotic protein BCL-2, BCL-XL, and upregulation of pro-apoptotic proteins BAX and BID, indicating that oridonin may serve as a potential anti-leukemia agent [28]. A proteomic identification of proteins involved in the anticancer activities of oridonin showed that the upregulation of Hsp70, serine/threonine kinase receptor-associated protein (STRAP), translationally controlled tumour protein (TCTP), Sti1, and protein phosphatase (PPase), as well as the downregulation of heterogeneous ribonucleoprotein (hnRNP)-E1 could be responsible for the apoptotic and G2/ $\mathrm{M}$-arresting effects of oridonin [29]. Oridonin also simultaneously induced apoptosis and autophagy of human multiple myeloma RPMI 8266 cells via regulation of SIRT1 nuclear protein [30]. Finally, oridonin was reported to induce HeLa cells apoptosis by altering balance of BCL2 and BAX protein expression [31]. As represented in Table 3, experimental evidence exists of the interaction between oridonin and many protein targets. This interaction in the cell may be responsible for the different activities observed with this compound. Moreover, as

Table 2 Effect of oidonin on cellular signaling pathways

\begin{tabular}{|c|c|c|c|}
\hline Signaling pathway & Cell line & Effect & References \\
\hline MAPK-p38 & BxPC-3 & $\begin{array}{l}\text { Enhances anti-tumor activity of } \\
\text { gemcitabine }\end{array}$ & {$[58]$} \\
\hline ASK1 and JNK1 & HuH-6 cells & Activated apoptosis signal & {$[33]$} \\
\hline NF kappaB and p38 & Inhibition & Induction of apoptosis & {$[72]$} \\
\hline ERK-p53 & Murine fibrosarcoma L929 cells & Activation & {$[35]$} \\
\hline PTK-Ras-Raf-JNK & Murine fibrosarcoma L929 cells & Inhibition & {$[35]$} \\
\hline Ras, JNK, and p38 & $\begin{array}{l}\text { Human cervical carcinoma HeLa } \\
\text { cells }\end{array}$ & Regulation & [19] \\
\hline LYN/mTOR & $\begin{array}{l}\mathrm{Ph}+\text { acute lymphoblastic leukemia } \\
\text { cells }\end{array}$ & Inhibition of activation & {$[52]$} \\
\hline $\begin{array}{l}\text { P65 or p50 forms of NF-kappa and its upstream } \\
\text { regulator I-kappa }\end{array}$ & $\begin{array}{l}\text { Human breast cancer cells MCF- } \\
10 \mathrm{~A}\end{array}$ & Decrease of expression & [39] \\
\hline PI3K/Akt & Cervical carcinoma HeLa cell line & Induction of apoptosis & {$[73]$} \\
\hline AP-1, NF-kappa B, and p38 & $\begin{array}{l}\text { Colorectal cancer cell lines Lovo } \\
\text { and SW480 }\end{array}$ & Dowregulation & {$[67]$} \\
\hline Akt and MAPK & Human osteosarcoma cells & Induction of apoptosis & {$[68]$} \\
\hline P38 and JNK & Human osteosarcoma cells & Activation & {$[68]$} \\
\hline Ras/Raf/ERK & A431 cells & Blockage & {$[76]$} \\
\hline Fas/FasL signaling & U937 cells & Regulation & [74] \\
\hline ERK & U937 cells & Induction of cell apoptosis & {$[75]$} \\
\hline Insulin-like growth factor 1 receptor signaling & Human melanoma A375-S2 cells & Induction of cell death & [76] \\
\hline Caspase 9 & A $375-S 2$ cells & Induction of apoptosis & [77] \\
\hline P53 and ERK & A375-S2 cells & Activation & {$[43]$} \\
\hline
\end{tabular}

$A k t$ protein kinase B, AP activator protein, $E R K$ extracellular signal-regulated kinase, $J N K$ c-Jun $\mathrm{N}$-terminal kinase, $M A P K$ mitogen-activated protein kinase, $m$ TOR mammalian target of rapamycin, $N F$ nuclear factor, PI3K phosphatidylinositol-3-kinase 
Table 3 Effect of oridonin on receptors, enzymes, and protein expression

\begin{tabular}{|c|c|c|c|}
\hline Receptor/enzyme/proteins & Cellular model & Effect & References \\
\hline P53, Bax & LNCap cells & Upregulation & {$[34]$} \\
\hline Bcl-2 & LNCap cells & Downregulation & {$[34]$} \\
\hline Androgen receptor & Carcinoma A431 & Downregulation & {$[78]$} \\
\hline Bax proteins & LNCap cells & Induction & [79] \\
\hline $\mathrm{Bax} / \mathrm{Bcl}-2$ ratio and cytochrome $\mathrm{c}$ & HeLa cells & Induction & {$[80]$} \\
\hline HSP 70 & Jurkat cells & Inhibition & {$[81]$} \\
\hline Nrf2 & UROtsa cells & Activation & {$[37]$} \\
\hline $\mathrm{P} 16, \mathrm{p} 21, \mathrm{p} 27$ and c-myc & Colorectal cancer cells & Regulation & {$[38]$} \\
\hline $\mathrm{HO}-1$ & Rat splenic lymphocytes & Induction & [18] \\
\hline $\mathrm{c}-\mathrm{Myc}$ & Cancer cells & Reduction of protein levels & {$[22]$} \\
\hline Pro-TNFalpha expression and IkB phosphorylation & L929 fibrosarcoma cells & Induction & {$[23]$} \\
\hline P53, Bcl-2 & L929 cells & $\begin{array}{l}\text { Promotes phosphorylation of } \mathrm{p} 53 \text { and } \\
\text { increased Bax expression }\end{array}$ & {$[82]$} \\
\hline AKT, FOXO transcription factor and GSK3 & Human osteosarcoma cells & Dephosphorylation & {$[26]$} \\
\hline EGFR & Human laryngeal cancer cells & Augmentation of apoptosis induction & {$[83]$} \\
\hline Fatty acid synthase & $\begin{array}{l}\text { Human colorectal cancer } \\
\text { cells }\end{array}$ & Suppression & {$[84]$} \\
\hline Tyrosine kinase and EGFR & $\begin{array}{l}\text { Human epidermoid } \\
\text { carcinoma A431 cells }\end{array}$ & $\begin{array}{l}\text { Decrease in tyrosine kinase activity and } \\
\text { blockage of EGFR }\end{array}$ & {$[85]$} \\
\hline Telomerase & K562 cells & Inhibition & {$[86]$} \\
\hline Bcl-2 & $\begin{array}{l}\text { Lung cancer cell line SPC-A- } \\
1\end{array}$ & Downregulation & {$[5]$} \\
\hline IL2, IFN gamma, IL12p40, and TNF alpha & Murine splenic lymphocytes & Inhibition & {$[55]$} \\
\hline Bax & $\begin{array}{l}\text { Lung cancer cell line SPC } \\
\text { A-1 }\end{array}$ & Upregulation & {$[5]$} \\
\hline Caspase-3-zymogen protein, Bcl-2, and Bcl-XL & HPB-ALL cells & Downregulation & {$[28]$} \\
\hline Telomerase, Bcl-2 & K562 cells & Downregulation & {$[54]$} \\
\hline Bax & K562 cells & Upregulation & {$[54]$} \\
\hline Telomerase & HL-60 cells & Downregulation & {$[87]$} \\
\hline hTERT mRNA, and telomerase & HL-60 cells & Dowregulation & {$[88]$} \\
\hline $\mathrm{Bcl}-2 / \mathrm{Bax}$ ratio & A549 cells & Induction of ratio decrease & {$[56]$} \\
\hline $\mathrm{PI} 3 \mathrm{~K}, \mathrm{PKC}$, and ERK & Macrophage-like U937 cells & Activation & {$[40]$} \\
\hline TNF alpha, IL-1 beta & Macrophage-like U937 cells & Release & [89] \\
\hline Apaf- 1 , cytochrome c, and caspase- 3 & $\begin{array}{l}\text { Gastric cancer cell line HGC- } \\
27\end{array}$ & Induction & {$[90]$} \\
\hline p-JNK, p-p38, p-p53, and p21 & HepG2 cells & Incretion & {$[42]$} \\
\hline B1/p-Cdc2 (Tyr15) complex & HepG2 cells & Increase & {$[42]$} \\
\hline Hsp70.1, STRAP, TCTP,Sti1 and PPase & HepG2 cells & Upregulation & {$[29]$} \\
\hline hnRNP-E1 & HepG2 cells & Downregulation & [29] \\
\hline $\begin{array}{l}\text { Bcl-2/Bax ratio, caspase-8, NF-kappa B(p65), } \\
\text { IKKalpha, phospho-mTOR }\end{array}$ & Human breast cancer cells & Reduction & {$[57]$} \\
\hline Cleaved PARP, Fas, and PPAR gamma & Human breast cancer cells & Increase & {$[57]$} \\
\hline NO, TNF alpha, IL6 & LPS-activated microglia & Inhibition & {$[45]$} \\
\hline Nucleoporin 88 and 214 & $\begin{array}{l}\text { OCIM2 acute } \\
\text { erythroleukemia cells }\end{array}$ & Protection from apoptosis & {$[91]$} \\
\hline SIRT1 & $\begin{array}{l}\text { Human multiple myeloma } \\
\text { cells }\end{array}$ & Regulation & {$[30]$} \\
\hline Raf-1, JNK, and p-JNK & HeLa cells & Induction & {$[92]$} \\
\hline BAFF & mice & Inhibition & [93] \\
\hline BIM & $\begin{array}{l}\text { Melanoma OCM-1 and } \\
\text { MUM2B cell lines }\end{array}$ & Upregulation & {$[110]$} \\
\hline
\end{tabular}


Table 3 continued

\begin{tabular}{llll}
\hline Receptor/enzyme/proteins & Cellular model & Effect & References \\
\hline Fatty acid synthase & Melanoma OCM-1 and & Downregulation & {$[110]$} \\
PARP & MUM2B cell lines & & Induction \\
\hline
\end{tabular}

$A K T$ protein kinase $\mathrm{B}, B A F F$ B-cell activating factor, $B c l$ B-cell lymphoma, $E G F R$ epidermal growth factor receptor, $F O X O$ forkhead box $\mathrm{O}$, GSK3 glycogen synthase kinase 3, hnRNP heterogeneous ribonucleoprotein, HSP heat shock protein, $h T E R T$ human telomerase reverse transcriptase, IFN interferon, $I L$ interleukin, $m R N A$ messenger RNA, $m T O R$ mammalian target of rapamycin, $N O$ nitric oxide, $P A R P$ poly (ADPribose) polymerase, $P I 3$ phosphatidylinositol-3, $P K C$ protein kinase $3, P P A R$ peroxisome proliferator-activated receptor, $P P a s e$ protein phosphatase, STRAP serine/threonine kinase receptor-associated protein, TCTP translationally controlled tumour protein, TNF tumor necrosis factor

Fig. 2 An overview of the molecular targets of oridonin and potential therapeutic effects. The interaction of oridonin with target proteins and signaling pathways regulates several cellular responses, including apoptosis, autophagy, inflammation, and neuroinflammation, either positively (indicated by green star) or negatively (indicated by yellow star). Thereby, a potential therapeutic effect of oridonin in the treatment of many diseases can be emphasized

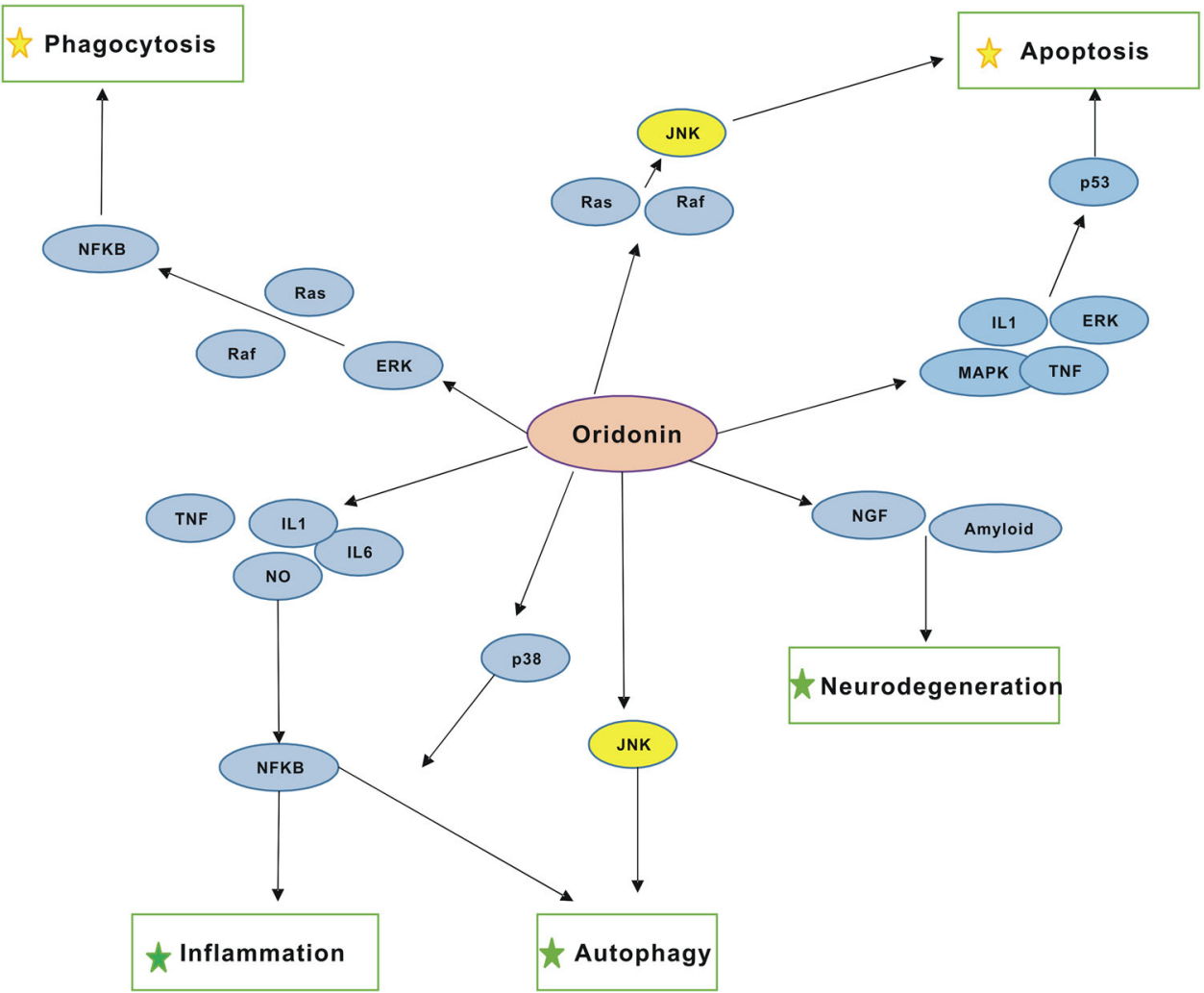

represented in Fig. 2, the connections between the different proteins affected by oridonin are crucial for the comprehension of its mechanism of action.

\subsection{Regulation of Transcription Factors and Signaling Pathways by Oridonin}

The activation of many transcription factors and signaling pathways is reported to be crucial in the mechanism of action of oridonin. Oridonin induced growth inhibition and apoptosis in cultured HuH-6 cells through ASK1/JNK1 signaling pathways [32], which enhances the understanding of the molecular mechanisms of oridonin in hepatoblastoma management [33]. Oridonin upregulated p53 and
BAX and downregulated BCL-2 expression in a dose-dependent manner in human prostate cell lines DU-145 [34]. Oridonin induction of apoptosis in L929 cells is regulated by ROS-mediated signaling pathways, and oridonin-induced autophagy may block apoptosis by upregulating p38 and nuclear factor (NF)-kappa B activation [35]. The autophagy induced by oridonin in HeLa cells was also investigated; results showed that the oridonin-induced autophagic process was negatively regulated by Ras but positively regulated by P38 and JNK MAPKs [19]. Oridonin also downregulated the phosphorylation of ERK, whereas those of JNK and P38 were upregulated in human breast cancer MCF-7 cells [36]. The transcription factor nuclear factor erythroid 2-related factor 2 (Nrf2) is a 
critical regulator of the cellular antioxidant response and xenobiotic metabolism. Oridonin activates the Nrf2 signaling pathway at a low subtoxic dose and is able to stabilize Nrf2 by blocking Nrf2 ubiquitination and degradation, leading to accumulation of the Nrf2 protein and activation of the Nrf2-dependent cytoprotective response [37]. Oridonin induced apoptosis and senescence in colorectal cancer cells by increasing histone hyperacetylation and regulation of p16, p21, p27, and c-myc [38]. The NF-kappa B-inhibiting capacity of oridonin has been studied in several different cell types. For instance, decreases in p6 or p50 forms of NF-kappa B and its upstream regulator I-kappa $\mathrm{B}$ were found in oridonintreated human cancer cells MCF-7 [39]. Oridonin also inhibits the proliferation of cells from lymphoid malignancies in association with blockade of the NF-kappa B signaling pathways [24]. NF-kappa B, AP-1, and P38 were all found to be downregulated in vivo after 4 weeks of treatment with oridonin in the colorectal cancer cell line Lovo, indicating that the downregulation of AP-1 could be an initial response to treatment by oridonin and this regulation in turn affects the expression of NF-kappa B and MAPK pathways, thereby inhibiting tumor growth [25]. The enhancement of phagocytosis of apoptotic bodies in human macrophage-like U937 cells by oridonin has been reported to occur through an activation of phosphatidylinositol-3 kinase (PI3K), protein kinase 3 (PKC), and ERKdependent signaling pathways [40]. Another study on the phagocytic activity demonstrated that Ras/Raf1/ERK signaling pathway-dependent I-kappa B-alpha degradation, resulting in NF-kappa $\mathrm{B}$ activation, participates in regulation of oridonin-enhanced phagocytosis [41]. Oridonin was reported to induce G2/M cell cycle arrest and apoptosis by increasing the expression levels of p-JNK, p-p38, p-p53, and p21 and elevating the level of cyclin B1/p-Cdc2 (Tyr15) complex in HepG2 cells [42]. Oridonin induced A375-S2 cell apoptosis by activating in parallel p53 and ERK pathways, simultaneously promoting the release of cytochrome $\mathrm{c}$ into the cytosol, resulting in apoptotic cell death [43].

\section{Immunomodulatory Effects}

Among the diverse activities of oridonin, its effect on the immune system and on pro-inflammatory mediators is one of the most important. Oridonin was reported to promote differentiation of cluster of differentiation (CD) $-4^{+} / \mathrm{CD} 25^{+}$ T-regulatory (Treg) cells, and to modulate the T-helper (Th)-1/Th2 balance in rat splenic lymphocytes [18]. An investigation of the effect of oridonin on intracellular tumor necrosis factor (TNF)-alpha expression revealed that the compound augments endogenous pro-TNF alpha expression and its upstream protein IkB phosphorylation [23]. Oridonin also blocked TNF-alpha and lipopolysaccharide-stimulated NF-kappa activity in Jurkat cells as well as in RAW264.7 murine macrophages [24]. Oridonin was reported to enhance phagocytosis of apoptotic bodies by activating PI3K-, PKC-, and ERK-dependent pathways in human macrophage-like U937 cells [40]. Another study demonstrated that Ras/Raf/ ERK signaling pathway-dependent Ikappa-Balpha degradation, resulting in NF-kappa B activation, participates in regulation of oridonin-enhanced phagocytosis, and that one of its effector functions is to induce the synthesis of interleukin (IL)-1 beta, which partially contributes to its phagocytic activity [41]. Oridonin facilitated the phagocytic activity against apoptotic cells through TNF alpha and IL-1 beta release, thereby contributing to its anti-tumor activities [44]. Moreover, oridonin pretreatment inhibits the release of pro-inflammatory mediators, including nitric oxide, TNF alpha, IL-1 beta, and IL-6, resulting in the inhibition of the DNA-binding activity of NF-kappa B [45]. Oridonin is also reported to be a potential modulator for trinitrobenzene sulfonic acid-induced colitis and other Th1/Th17-mediated inflammatory diseases [108].

\section{The Role of Reactive Oxygen Species in Oridonin Activity}

ROS are important signaling molecules involved in immune defenses, cell proliferation, and cell repair. Oridonin has been shown to increase intracellular hydrogen peroxide levels and reduce the glutathione content in colorectal cancer cells (Table 4). These effects were important in oridonin-induced apoptosis and senescence in these cells [46]. Another study showed that oridonin stimulates mitochondrial transmembrane permeabilization in a ROSdependent manner, and these ROS produced are responsible for the oridonin-induced HepG2 apoptosis through p53, MAPK, and mitochondrial signaling pathways [47]. The growth inhibitory activity of oridonin was studied in L929 cells, where a rapid generation of ROS was noted as being triggered by oridonin, and subsequently upregulation of phospho-p53 expression and increased expression ratio of BAX/BCL-2 was observed. In this study, it was demonstrated that oridonin induced cell death in murine fibrosarcoma L929 by enhancing ROS generation [48]. It was also demonstrated that the hydroxyl radical $\mathrm{OH}(\cdot)$ plays a pivotal role in oridonin-induced apoptosis and autophagy in human epidermoid carcinoma A431 cells [49]. Oridonin was reported to cause a modest level of ROS generation in $\mathrm{U} 937$ cells, with hydrogen peroxide $\left(\mathrm{H}_{2} \mathrm{O}_{2}\right)$ and hydrogen free radical $\mathrm{OH}(\cdot)$ as the major types. These two types of ROS were positive regulators involved in oridonin-enhanced engulfment of apoptotic cells. $\mathrm{H}_{2} \mathrm{O}_{2}$ and 
Table 4 Effect of oridonin on cellular models

\begin{tabular}{|c|c|c|}
\hline Effect & Cell type/model & References \\
\hline Cytotoxic effect & Human Hep G2, COLO 205, MCF-7 and HL-60 cancer cells & [94] \\
\hline Cytotoxicity & HL-60, HO-8910, and A-549 human tumor cells & [95] \\
\hline Anti-proliferative activity & $\begin{array}{l}\text { Human cell lines derived from prostate (DU-145, LNCaP), breast } \\
(\mathrm{MCF}-7) \text {, and ovarian (A2780 and PTX10) cancers }\end{array}$ & {$[34]$} \\
\hline Induction of apoptosis and autophagy & Murine fibrosarcoma L929 cells & {$[72]$} \\
\hline $\begin{array}{l}\text { Intracellular ROS generation, lipid peroxidation as well as } \\
\text { decrease in SOD and glutathione activities }\end{array}$ & Murine fibrosarcoma L929 cells & {$[72]$} \\
\hline Induces $\mathrm{G} 2 / \mathrm{M}$ arrest and apoptosis & Murine fibrosarcoma L929 cells & {$[35]$} \\
\hline Induction of apoptosis and autophagy & HeLa cells & {$[80]$} \\
\hline Confers protection against arsenic-induced toxicity & UROtsa cells & {$[37]$} \\
\hline Growth inhibition and inhibition of apoptosis & MCF-/breast cancer cells & {$[21]$} \\
\hline $\begin{array}{l}\text { Induce apoptosis and senescence and increase histone hyper } \\
\text { acetylation }\end{array}$ & Colorectal cancer cells & {$[38]$} \\
\hline $\begin{array}{l}\text { Induces apoptosis and senescence by increasing } \mathrm{H}_{2} \mathrm{O}_{2} \text { and } \\
\text { glutathione depletion }\end{array}$ & Colorectal cancer cells & [46] \\
\hline Inhibition of proliferation & MKN45 cells & [96] \\
\hline Induced S/G2M arrest and G1/S block & MCF-7 cells & [39] \\
\hline Promotes differentiation & $\mathrm{CD} 4^{+} / \mathrm{CD} 25^{+} \mathrm{T}-\mathrm{reg}$ & [18] \\
\hline Induced TGF-beta and IL-10 & Rat splenic lymphocytes & [18] \\
\hline \multicolumn{3}{|l|}{ Inhibited IL-2 and IFN-gamma } \\
\hline Induction of $\mathrm{G}(2) \mathrm{M}$ phase arrest and apoptosis & Human laryngeal carcinoma cells & [97] \\
\hline Enhance phagocytosis of apoptotic bodies & Human macrophage-like U937 cells & {$[40]$} \\
\hline Induction of cell motility & Murine melanoma K1735M2 cells & [98] \\
\hline Induction of $\mathrm{G} 2 / \mathrm{M}$ cell cycle arrest & HepG2 cells & [42] \\
\hline
\end{tabular}

$C D$ cluster of differentation, $I F N$ interferon, $I L$ interleukin, $R O S$ reactive oxygen species, $S O D$ superoxide dismutase, $T G F$ transforming growth factor, T-reg T-regulatory cells

$\mathrm{OH}$ generation also activated PI3K-Akt and phospholipase C gamma-protein kinase C (PLC gamma)-Ras-Raf-ERK signaling pathways, which are essential for oridonin-induced apoptosis [50]. Nitric oxide was reported to augment oridonin-induced efferocytosis (phagocytosis of apoptotic cells) in human histocytic lymphoma U937 cells via autophagy and the NF-kappa B-cyclooxygenase-2-IL-1beta pathway [51]. Oridonin was reported as inducing apoptosis and autophagy of human multiple myeloma RPMI8266 cells via the regulation of intracellular ROS generation [30].

\section{Oridonin: Top Interacting Genes}

Oridonin is considered to be a safe and multi-targeted compound and has been reported to interact with many genes. We used the Comparative Toxicogenomics Database to find the top interacting genes, and observed that HMOX1, BLC2, CASP3, IFNG, IL10, PARP1, and TGFB1 are the most important (Table 5). HMOX1 (heme oxygenase 1, EC 1.14.99.3) is an essential enzyme in heme catabolism that cleaves heme to form biliverdin. Oridonin is reported to increase the activity of HMOX 1 messenger RNA (mRNA) and protein in rat splenic lymphocytes [18]. Oridonin is also reported to downregulate anti-apoptotic protein BCL-2 expression in many cancer cells [5, 24, 28, $34,52-54]$. Oridonin also inhibits/decreases the expression of IL2 protein in rat splenic lymphocytes and in BALB/c mouse splenic lymphocytes [18, 55]. Oridonin decreased the expression of IFN gamma (IFNG) and increased the expression of IL10 protein [18]. Oridonin increases the cleavage of caspase-3 protein $[26,56]$.

PARP1 is an enzyme that in humans is encoded by the PARPl gene, which is involved in differentiation, proliferation, and tumor transformation. Oridonin was reported to increase the cleavage of PARP1 protein in highly metastatic human breast cancer cells [57]. Transforming growth factor beta 1 (TGFB1) is a polypeptide member of the TGFB superfamily of secreted cytokines that perform many cellular functions, including apoptosis, cell differentiation, and cell proliferation. In humans, TGFB1 is encoded by the TGFBl gene, and oridonin is reported to increase expression of the TGFB1 protein [18]. 
Table 5 Oridonin top interacting genes

\begin{tabular}{lll}
\hline Interacting gene & Interaction & References \\
\hline IL10 & Increases expression of the protein & {$[18]$} \\
IL2 & Increases expression of the protein & {$[18]$} \\
IFNG & Decreases expression of the protein & {$[55]$} \\
HMOX1 & Increases mRNA expression & {$[18]$} \\
HMOX1 & Increases expression of the protein & {$[18]$} \\
CASP3 & Increases cleavage of the protein & {$[105]$} \\
BCL2 & Decreases expression of the protein & {$[106]$} \\
PARP1 & Increases cleavage of the protein & {$[20]$} \\
TGFB1 & Increases expression of the protein & {$[107]$} \\
\hline
\end{tabular}

$B C L$ B-cell lymphoma, $H M O X$ heme oxygenase, IFNG interferon gamma, $I L$ interleukin, $m R N A$ messenger RNA, PARP poly (ADPribose) polymerase, $T G F B$ transforming growth factor $\mathrm{B}$

\section{Adjuvant/Synergistic Effects}

In order to increase the effect of oridonin, it has been combined with other compounds with reported therapeutic effects. Oridonin could potentiate the effects of gemcitabine in $\mathrm{PaCa}$ pancreatic cancer cells through the MAPK-p38 signaling pathway [58]. An oridonin and arsenic trioxide combination were reported to enhance tumor-suppression activity in a human hepatocellular carcinoma (HCC) model compared with single agent treatment in vivo, demonstrating that oridonin can sensitize $\mathrm{HCC}$ cells to $\mathrm{As} 2 \mathrm{O} 3$ treatment and therefore facilitate the optimization of As2O3 therapy for HCC patients [59]. Oridonin in combination with imatinib revealed a synergetic anti-leukemia effect in $\mathrm{Ph}+$ acute lymphoblastic leukemia cells in vitro by inhibiting the activation of the LYN/mammalian target of rapamycin (mTOR) signaling pathway [52]. A promising combined activity of oridonin and wogonin was reported in advanced-stage ovarian cancer cells [60]. The synergistic effect of oridonin and cisplatin on cytotoxicity and DNA cross-link against mouse sarcoma $\mathrm{S} 180$ cells in culture was reported to increase after combining the two drugs [61].

\section{Oridonin Formulation and Bioavailability}

Despite the promising effects of oridonin, its clinical development has been hampered by its limited aqueous solubility and bioavailability [62]. Moreover, the oridonin solution is not stable [63]. The development and application of oridonin is also reported to be limited by its rapid plasma clearance. To solve this problem, many different approaches have been developed to increase the solubility and bioavailability of oridonin. PEGylated oridonin linked with succinic acid (SA) as a spacer moiety (PEG-SA-ORI) was synthesized [64]. All polymeric conjugates obtained showed satisfactory aqueous solubility, and in vitro studies showed that the drug solubility increased, suggesting that PEGylation could be a promising method to increase the efficacy of oridonin. Oridonin nanosuspension was reported to be more effective than free oridonin on $\mathrm{G}(2) / \mathrm{M}$ cell cycle arrest and apoptosis in the human pancreatic cancer PANC-1 cell line [65]. The drug carrier monomethoxy poly(ethylene glycol)poly(epsilon-caprolactone) (MPEG-PCL) was used to increase the water solubility of oridonin and the prepared oridonin micelles obtained presented great potential for direct intravascular administration [66]. A self-microemulsifying drug-delivery system (SMEDDS) was developed to enhance the bioavailability of oridonin. The absorption of oridonin from SMEDDS showed a 2.2-fold increase in relative bioavailability compared with that of the suspension, demonstrating the promising use of SMEDDS for the oral delivery of oridonin [67]. Oridonin-loaded nanoparticles coated with galactosylated chitosan (ORI-GC-NP) was reported as a promising intravenous drug-delivery system for oridonin that could be developed as an alternative to the conventional oridonin preparations [68]. In a recent study, a novel biotin-modified nanostructured lipid carrier was developed to enhance the bioavailability of oridonin [109].

\section{Oridonin as a Therapeutic Agent in Many Diseases}

Oridonin could be associated with the treatment of many diseases via interaction with many inference networks. The Comparative Toxicogenomics Database reports 232 different diseases that could be directly or indirectly associated with oridonin and the different inference networks involved. Based on these observations, the compound really needs to be investigated for the treatment of many other diseases aside from cancer. For instance, a recent publication showed oridonin was able to ameliorate neuropathological changes and behavioral deficits in a mouse model of cerebral amyloidosis by attenuating b-amyloid deposition, plaque-associated APP expression, and microglial activation in the brain of transgenic mice [9]. Oridonin was shown to lower pulmonary artery pressure in rats [68]. It is therefore presented as a new research target for future and promising investigations.

\section{Structure/Activity Relationship}

The chemical structure of oridonin has been modified in some studies to increase its therapeutic effects. Therefore, overcoming synthetic challenges of oridonin A-ring structural diversification is attracting high levels of interest. Regio and stereoselective installation of azides and 1, 2, 3-triazoles at the $\mathrm{C}-1, \mathrm{C}-2$, or $\mathrm{C}-3$ position was shown to 
improve the effect of oridonin [69]. New nitrogen-enriched oridonin analogs obtained by rationally modifying the structure of oridonin with thiazole-fused in the A-ring through an efficient protecting group-free synthetic strategy were shown to enhance the anti-cancer profile, as well as to improve the water solubility [62].

Oridonin was reported to exhibit moderate effects against highly aggressive cancers. Therefore, efficient and regioselective enone construction strategies have been established. With oridonin ring A-based diverse constructions of enone functionality, novel dienone analogs were produced and reported effective against highly aggressive breast cancer by inducing apoptosis [70]. The structure-activity relationship of six ent-kaurane diterpenoids, including oridonin, on cytotoxicity and DNA damage potential against three human tumor HepG2, GLC-82, and HL-60 cell lines was reported. It was found that exo-methylene cyclopentanone in the molecular structure is important in maintaining the cytotoxicity and DNA damage potential of oridonin. With an $\mathrm{OH}$ group at position $\mathrm{C} 1$, oridonin exhibited a higher cytotoxicity and DNA damage potential on the tumor cells than lasiokaurin (OAc group at position $\mathrm{C} 1)$ [71].

\section{Conclusion}

Oridonin has shown promising effects in the modulation of molecular pathways in different cell models. Several molecular targets have already been identified, which can partially explain the broad range of in vitro biological effects of the compound. The compound has also shown promising effects in the treatment of diseases other than cancer. Therefore, further studies aiming at investigating the effect of oridonin in many other disease treatments could be promising.

\section{Compliance with Ethical Standards}

Conflicts of interest No funding was received in the preparation of this review. Brice Ayissi Owona and Herman J Schluesener have no conflicts of interest to declare.

Open Access This article is distributed under the terms of the Creative Commons Attribution-NonCommercial 4.0 International License (http://creativecommons.org/licenses/by-nc/4.0/), which permits any noncommercial use, distribution, and reproduction in any medium, provided you give appropriate credit to the original author(s) and the source, provide a link to the Creative Commons license, and indicate if changes were made.

\section{References}

1. Kuo LM, Kuo CY, Lin CY, Hung MF, Shen JJ, Hwang TL. Intracellular glutathione depletion by oridonin leads to apoptosis in hepatic stellate cells. Molecules. 2014;19(3):3327-44.
2. Kadota S, Basnet P, Ishii E, Tamura T, Namba T. Antibacterial activity of trichorabdal A from Rabdosia trichocarpa against Helicobacter pylori. Zentralblatt fur Bakteriologie: Int J Med Microbiol. 1997;286(1):63-7.

3. Liu Y, Liu YZ, Zhang RX, Wang X, Meng ZJ, Huang J, Wu K, Luo JY, Zuo GW, Chen L, et al. Oridonin inhibits the proliferation of human osteosarcoma cells by suppressing Wnt/betacatenin signaling. Int J Oncol. 2014;45(2):795-803.

4. Xu S, Li D, Pei L, Yao H, Wang C, Cai H, Yao H, Wu X, Xu J. Design, synthesis and antimycobacterial activity evaluation of natural oridonin derivatives. Bioorg Med Chem Lett. 2014;24(13):2811-4

5. Liu JJ, Huang RW, Lin DJ, Peng J, Wu XY, Pan XL, Li MQ, Lin Q. Anti-proliferative effects of oridonin on SPC-A-1 cells and its mechanism of action. J Int Med Res. 2004;32(6):617-25.

6. Dal Piaz F, Cotugno R, Lepore L, Vassallo A, Malafronte N, Lauro G, Bifulco G, Belisario MA, De Tommasi N. Chemical proteomics reveals HSP70 1A as a target for the anticancer diterpene oridonin in Jurkat cells. J Proteomics. 2013;82:14-26.

7. Tan W, Lu J, Huang M, Li Y, Chen M, Wu G, Gong J, Zhong Z, $\mathrm{Xu} Z$, Dang Y, et al. Anti-cancer natural products isolated from chinese medicinal herbs. Chin Med. 2011;6(1):27.

8. Duan HQ, Li MY, Gao L, Zhang JF, Wang W, Li Y, Ma YG, Wang CB. Mechanism concerning antitumor effect of oridonin on multiple myeloma cell line U266. Zhongguo shi yan xue ye xue za zhi/Zhongguo bing li sheng li xue hui = J Exp Hematol/ Chin Assoc Pathophysiol. 2014;22(2):364-9.

9. Zhang ZY, Daniels R, Schluesener HJ. Oridonin ameliorates neuropathological changes and behavioural deficits in a mouse model of cerebral amyloidosis. J Cell Mol Med. 2013;17(12): 1566-76.

10. Huang J, Wu L, Tashiro S, Onodera S, Ikejima T. Fibroblast growth factor-2 suppresses oridonin-induced L929 apoptosis through extracellular signal-regulated kinase-dependent and phosphatidylinositol 3-kinase-independent pathway. J Pharmacol Sci. 2006;102(3):305-13.

11. Bu HQ, Liu DL, Wei WT, Chen L, Huang H, Li Y, Cui JH. Oridonin induces apoptosis in SW1990 pancreatic cancer cells via p53- and caspase-dependent induction of p38 MAPK. Oncol Rep. 2014;31(2):975-82.

12. Zhang CL, Wu LJ, Tashiro S, Onodera S, Ikejima T. Oridonin induces a caspase-independent but mitochondria- and MAPKdependent cell death in the murine fibrosarcoma cell line L929. Biol Pharm Bull. 2004;27(10):1527-31.

13. Liu Y, Liu JH, Chai K, Tashiro S, Onodera S, Ikejima T. Inhibition of c-Met promoted apoptosis, autophagy and loss of the mitochondrial transmembrane potential in oridonin-induced A549 lung cancer cells. J Pharm Pharmacol. 2013;65(11): $1622-42$.

14. Harris ES, Cao S, Schoville SD, Dong C, Wang W, Jian Z, Zhao Z, Eisenberg DM, Clardy J. Selection for high oridonin yield in the Chinese medicinal plant Isodon (Lamiaceae) using a combined phylogenetics and population genetics approach. PLoS One. 2012;7(11):e50753.

15. Dong CM, Su XH, Wang L, Wang WL. Effect of N, P, K on yield and quality of Rabdosia rubescens. Zhong yao cai = Zhongyaocai $=\mathrm{J}$ Chin Med Mater. 2008;31(6):808-811.

16. Du Y, Liu P, Shi X, Jin Y, Wang Q, Zhang X, Sheng X, Zhang L. A novel analysis method for diterpenoids in rat plasma by liquid chromatography-electrospray ionization mass spectrometry. Anal Biochem. 2010;407(1):111-9.

17. Lu Y, Sun C, Liu R, Pan Y. Effective two-dimensional counter-current chromatographic method for simultaneous isolation and purification of oridonin and ponicidin from the crude extract of Rabdosia rubescens. J Chromatogr A. 2007;1146(1):125-30. 
18. Hu AP, Du JM, Li JY, Liu JW. Oridonin promotes CD4+/ CD25+ Treg differentiation, modulates Th1/Th2 balance and induces HO-1 in rat splenic lymphocytes. Inflamm Res. 2008;57(4):163-70.

19. Cui Q, Tashiro S, Onodera S, Minami M, Ikejima T. Oridonin induced autophagy in human cervical carcinoma HeLa cells through Ras, JNK, and P38 regulation. J Pharmacol Sci. 2007;105(4):317-25.

20. Cui Q, Yu JH, Wu JN, Tashiro S, Onodera S, Minami M, Ikejima T. P53-mediated cell cycle arrest and apoptosis through a caspase-3- independent, but caspase-9-dependent pathway in oridonin-treated MCF-7 human breast cancer cells. Acta Pharmacol Sin. 2007;28(7):1057-66.

21. Feng FF, Zhang DR, Tian KL, Lou HY, Qi XL, Wang YC, Duan CX, Jia LJ, Wang FH, Liu Y, et al. Growth inhibition and induction of apoptosis in MCF-7 breast cancer cells by oridonin nanosuspension. Drug Deliv. 2011;18(4):265-71.

22. Huang HL, Weng HY, Wang LQ, Yu CH, Huang QJ, Zhao PP, Wen JZ, Zhou H, Qu LH. Triggering Fbw7-mediated proteasomal degradation of c-Myc by oridonin induces cell growth inhibition and apoptosis. Mol Cancer Ther. 2012;11(5):1155-65.

23. Huang J, Wu L, Tashiro S, Onodera S, Ikejima T. A comparison of the signal pathways between the TNF alpha- and oridonininduced murine L929 fibrosarcoma cell death. Acta Med Okayama. 2005;59(6):261-70.

24. Ikezoe T, Yang $\mathrm{Y}$, Bandobashi $\mathrm{K}$, Saito $\mathrm{T}$, Takemoto $\mathrm{S}$, Machida H, Togitani K, Koeffler HP, Taguchi H. Oridonin, a diterpenoid purified from Rabdosia rubescens, inhibits the proliferation of cells from lymphoid malignancies in association with blockade of the NF-kappa B signal pathways. Mol Cancer Ther. 2005;4(4):578-86.

25. Jin H, Tan X, Liu X, Ding Y. Downregulation of AP-1 gene expression is an initial event in the oridonin-mediated inhibition of colorectal cancer: studies in vitro and in vivo. J Gastroenterol Hepatol. 2011;26(4):706-15.

26. Jin S, Shen JN, Wang J, Huang G, Zhou JG. Oridonin induced apoptosis through Akt and MAPKs signaling pathways in human osteosarcoma cells. Cancer Biol Ther. 2007;6(2):261-8.

27. Li D, Wu LJ, Tashiro S, Onodera S, Ikejima T. Oridonin induces human epidermoid carcinoma A431 cell apoptosis through tyrosine kinase and mitochondrial pathway. J Asian Nat Prod Res. 2008;10(1-2):77-87.

28. Liu JJ, Huang RW, Lin DJ, Wu XY, Peng J, Pan XL, Lin Q, Hou $\mathrm{M}$, Zhang MH, Chen F. Antiproliferation effects of oridonin on HPB-ALL cells and its mechanisms of action. Am J Hematol. 2006;81(2):86-94.

29. Wang H, Ye Y, Pan SY, Zhu GY, Li YW, Fong DW, Yu ZL. Proteomic identification of proteins involved in the anticancer activities of oridonin in HepG2 cells. Phytomedicine. 2011;18(2-3):163-9.

30. Zeng R, Chen Y, Zhao S, Cui GH. Autophagy counteracts apoptosis in human multiple myeloma cells exposed to oridonin in vitro via regulating intracellular ROS and SIRT1. Acta Pharmacol Sin. 2012;33(1):91-100.

31. Zhang CL, Wu LJ, Tashiro S, Onodera S, Ikejima T. Oridonin induces apoptosis of HeLa cells via altering expression of $\mathrm{Bcl}-2 /$ Bax and activating caspase-3/ICAD pathway. Acta Pharmacol Sin. 2004;25(5):691-8.

32. Wang K, Zhang ZQ. Determination of oridonin and rosemarinic acid in Rabdosia rubescens by HPLC. Zhong yao cai = Zhongyaocai $=$ J Chin Med Mater. 2007;30(11):1396-1398.

33. Cai DT, Jin H, Xiong QX, Liu WG, Gao ZG, Gu GX, Qiu YH. ER stress and ASK1-JNK activation contribute to oridonin-induced apoptosis and growth inhibition in cultured human hepatoblastoma HuH-6 cells. Mol Cell Biochem. 2013;379(1-2):161-9.
34. Chen S, Gao J, Halicka HD, Huang X, Traganos F, Darzynkiewicz Z. The cytostatic and cytotoxic effects of oridonin (Rubescenin), a diterpenoid from Rabdosia rubescens, on tumor cells of different lineage. Int J Oncol. 2005;26(3):579-88.

35. Cheng Y, Qiu F, Ye YC, Tashiro S, Onodera S, Ikejima T. Oridonin induces G2/M arrest and apoptosis via activating ERKp53 apoptotic pathway and inhibiting PTK-Ras-Raf-JNK survival pathway in murine fibrosarcoma L929 cells. Arch Biochem Biophys. 2009;490(1):70-5.

36. Cui Q, Tashiro S, Onodera S, Minami M, Ikejima T. Autophagy preceded apoptosis in oridonin-treated human breast cancer MCF-7 cells. Biol Pharm Bull. 2007;30(5):859-64.

37. Du Y, Villeneuve NF, Wang XJ, Sun Z, Chen W, Li J, Lou H, Wong PK, Zhang DD. Oridonin confers protection against arsenic-induced toxicity through activation of the Nrf2-mediated defensive response. Environ Health Perspect. 2008;116(9): 1154-61.

38. Gao FH, Hu XH, Li W, Liu H, Zhang YJ, Guo ZY, Xu MH, Wang ST, Jiang B, Liu F, et al. Oridonin induces apoptosis and senescence in colorectal cancer cells by increasing histone hyperacetylation and regulation of p16, p21, p27 and c-myc. BMC Cancer. 2010;10:610.

39. Hsieh TC, Wijeratne EK, Liang JY, Gunatilaka AL, Wu JM. Differential control of growth, cell cycle progression, and expression of NF-kappaB in human breast cancer cells MCF-7, MCF-10A, and MDA-MB-231 by ponicidin and oridonin, diterpenoids from the chinese herb Rabdosia rubescens. Biochem Biophys Res Commun. 2005;337(1):224-31.

40. Liu YQ, You S, Tashiro S, Onodera S, Ikejima T. Activation of phosphoinositide 3-kinase, protein kinase C, and extracellular signal-regulated kinase is required for oridonin-enhanced phagocytosis of apoptotic bodies in human macrophage-like U937 cells. J Pharmacol Sci. 2005;98(4):361-71.

41. Liu YQ, You S, Tashiro S, Onodera S, Ikejima T. Roles of Ras and extracellular signal-regulated kinase-dependent IkappaBalpha degradation in oridonin-enhanced phagocytosis of apoptotic cells by human macrophage-like U937 cells. Int Immunopharmacol. 2006;6(2):260-8.

42. Wang H, Ye Y, Chui JH, Zhu GY, Li YW, Fong DW, Yu ZL. Oridonin induces $\mathrm{G} 2 / \mathrm{M}$ cell cycle arrest and apoptosis through MAPK and p53 signaling pathways in HepG2 cells. Oncol Rep. 2010;24(3):647-51.

43. Zhang CL, Wu LJ, Zuo HJ, Tashiro S, Onodera S, Ikejima T. Cytochrome c release from oridonin-treated apoptotic A375-S2 cells is dependent on p53 and extracellular signal-regulated kinase activation. J Pharmacol Sci. 2004;96(2):155-63.

44. Liu YQ, You S, Zhang CL, Tashiro S, Onodera S, Ikejima T. Oridonin enhances phagocytosis of UV-irradiated apoptotic U937 cells. Biol Pharm Bull. 2005;28(3):461-7.

45. Xu Y, Xue Y, Wang Y, Feng D, Lin S, Xu L. Multiple-modulation effects of Oridonin on the production of proinflammatory cytokines and neurotrophic factors in LPS-activated microglia. Int Immunopharmacol. 2009;9(3):360-5.

46. Gao FH, Liu F, Wei W, Liu LB, Xu MH, Guo ZY, Li W, Jiang $\mathrm{B}, \mathrm{Wu} \mathrm{YL}$. Oridonin induces apoptosis and senescence by increasing hydrogen peroxide and glutathione depletion in colorectal cancer cells. Int J Mol Med. 2012;29(4):649-55.

47. Huang J, Wu L, Tashiro S, Onodera S, Ikejima T. Reactive oxygen species mediate oridonin-induced HepG2 apoptosis through p53, MAPK, and mitochondrial signaling pathways. J Pharmacol Sci. 2008;107(4):370-9.

48. Wu JN, Huang J, Yang J, Tashiro S, Onodera S, Ikejima T. Caspase inhibition augmented oridonin-induced cell death in murine fibrosarcoma 1929 by enhancing reactive oxygen species generation. J Pharmacol Sci. 2008;108(1):32-9. 
49. Yu Y, Fan SM, Song JK, Tashiro S, Onodera S, Ikejima T. Hydroxyl radical (.OH) played a pivotal role in oridonin-induced apoptosis and autophagy in human epidermoid carcinoma A431 cells. Biol Pharm Bull. 2012;35(12):2148-59.

50. Zang L, He H, Xu Q, Yu Y, Zheng N, Liu W, Hayashi T, Tashiro S, Onodera S, Ikejima T. Reactive oxygen species $\mathrm{H} 2 \mathrm{O} 2$ and $* \mathrm{OH}$, but not $\mathrm{O} 2 *(-)$ promote oridonin-induced phagocytosis of apoptotic cells by human histocytic lymphoma U937 cells. Int Immunopharmacol. 2013;15(2):414-23.

51. Zang L, He H, Ye Y, Liu W, Fan S, Tashiro S, Onodera S, Ikejima T. Nitric oxide augments oridonin-induced efferocytosis by human histocytic lymphoma U937 cells via autophagy and the NF-kappaB-COX-2-IL-1beta pathway. Free Radical Res. 2012;46(10):1207-19.

52. Guo Y, Shan Q, Gong Y, Lin J, Yang X, Zhou R. Oridonin in combination with imatinib exerts synergetic anti-leukemia effect in $\mathrm{Ph}+$ acute lymphoblastic leukemia cells in vitro by inhibiting activation of LYN/mTOR signaling pathway. Cancer Biol Ther. 2012;13(13):1244-54.

53. Li J, Yang L, Wu H. Oridonin induced the apoptosis of PC-3 cells and its mechanism. Zhong nan da xue xue bao Yi xue ban = J Cent S Univ Med Sci. 2011;36(8):754-759.

54. Liu JJ, Huang RW, Lin DJ, Wu XY, Peng J, Pan XL, Song YQ, Lin Q, Hou M, Wang DN, et al. Oridonin-induced apoptosis in leukemia K562 cells and its mechanism. Neoplasma. 2005;52(3):225-30.

55. Liu J, Yang F, Zhang Y, Li J. Studies on the cell-immunosuppressive mechanism of Oridonin from Isodon serra. Int Immunopharmacol. 2007;7(7):945-54.

56. Liu Y, Shi QF, Qi M, Tashiro S, Onodera S, Ikejima T. Interruption of hepatocyte growth factor signaling augmented oridonin-induced death in human non-small cell lung cancer A549 cells via c-met-nuclear factor-kappaB-cyclooxygenase- 2 and c-Met-Bcl-2-caspase-3 pathways. Biol Pharm Bull. 2012;35(7): $1150-8$.

57. Wang S, Zhong Z, Wan J, Tan W, Wu G, Chen M, Wang Y. Oridonin induces apoptosis, inhibits migration and invasion on highly-metastatic human breast cancer cells. Am J Chin Med. 2013;41(1):177-96.

58. Bu HQ, Luo J, Chen H, Zhang JH, Li HH, Guo HC, Wang ZH, Lin SZ. Oridonin enhances antitumor activity of gemcitabine in pancreatic cancer through MAPK-p38 signaling pathway. Int J Oncol. 2012;41(3):949-58.

59. Chen G, Wang K, Yang BY, Tang B, Chen JX, Hua ZC. Synergistic antitumor activity of oridonin and arsenic trioxide on hepatocellular carcinoma cells. Int J Oncol. 2012;40(1):139-47.

60. Chen S, Cooper M, Jones M, Madhuri TK, Wade J, Bachelor A, Butler-Manuel S. Combined activity of oridonin and wogonin in advanced-stage ovarian cancer cells: sensitivity of ovarian cancer cells to phyto-active chemicals. Cell Biol Toxicol. 2011;27(2):133-47.

61. Gao ZG, Ye QX, Zhang TM. Synergistic effect of oridonin and cisplatin on cytotoxicity and DNA cross-link against mouse sarcoma S180 cells in culture. Zhongguo yao li xue bao =Acta Pharmacol Sin. 1993;14(6):561-4.

62. Ding C, Zhang Y, Chen H, Yang Z, Wild C, Chu L, Liu H, Shen Q, Zhou J. Novel nitrogen-enriched oridonin analogues with thiazole-fused A-ring: protecting group-free synthesis, enhanced anticancer profile, and improved aqueous solubility. J Med Chem. 2013;56(12):5048-58.

63. Xu J, Zhao J, Wang J, Feng N, Tan R, Liu Y. Study on stability of oridonin solution. Zhongguo Zhong yao za zhi = Zhongguo zhongyao zazhi =China J Chin Mater Med. 2009;34(1):47-9.

64. Shen J, Zhang D, Zhao Z, Jia L, Zheng D, Liu G, Hao L, Zhang Q, Tian X, Li C, et al. Synthesis, characterization, in vitro and in vivo evaluation of PEGylated oridonin conjugates. Int $\mathbf{J}$ Pharm. 2013;456(1):80-6.

65. Qi X, Zhang D, Xu X, Feng F, Ren G, Chu Q, Zhang Q, Tian K. Oridonin nanosuspension was more effective than free oridonin on G2/M cell cycle arrest and apoptosis in the human pancreatic cancer PANC-1 cell line. Int J Nanomed. 2012;7:1793-804.

66. Xue B, Wang Y, Tang X, Xie P, Wang Y, Luo F, Wu C, Qian Z. Biodegradable self-assembled MPEG-PCL micelles for hydrophobic oridonin delivery in vitro. J Biomed Nanotechnol. 2012;8(1):80-9.

67. Zhang P, Liu Y, Feng N, Xu J. Preparation and evaluation of self-microemulsifying drug delivery system of oridonin. Int $\mathbf{J}$ Pharm. 2008;355(1-2):269-76.

68. Zheng D, Duan C, Zhang D, Jia L, Liu G, Liu Y, Wang F, Li C, Guo H, Zhang Q. Galactosylated chitosan nanoparticles for hepatocyte-targeted delivery of oridonin. Int $\mathrm{J}$ Pharm. 2012;436(1-2):379-86.

69. Ding C, Zhang Y, Chen H, Wild C, Wang T, White MA, Shen Q, Zhou J. Overcoming synthetic challenges of oridonin A-ring structural diversification: regio- and stereoselective installation of azides and 1,2,3-triazoles at the C-1, C-2, or C-3 position. Org Lett. 2013;15(14):3718-21.

70. Ding C, Zhang Y, Chen H, Yang Z, Wild C, Ye N, Ester CD, Xiong A, White MA, Shen Q, et al. Oridonin ring A-based diverse constructions of enone functionality: identification of novel dienone analogues effective for highly aggressive breast cancer by inducing apoptosis. J Med Chem. 2013;56(21): 8814-25.

71. Ding L, Zhou Q, Wang L, Wang W, Zhang S, Liu B. Comparison of cytotoxicity and DNA damage potential induced by ent-kaurene diterpenoids from Isodon plant. Nat Prod Res. 2011;25(15):1402-11.

72. Cheng Y, Qiu F, Ikejima T. Molecular mechanisms of oridonininduced apoptosis and autophagy in murine fibrosarcoma L929 cells. Autophagy. 2009;5(3):430-1.

73. Hu HZ, Yang YB, Xu XD, Shen HW, Shu YM, Ren Z, Li XM, Shen HM, Zeng HT. Oridonin induces apoptosis via PI3K/Akt pathway in cervical carcinoma HeLa cell line. Acta Pharmacol Sin. 2007;28(11):1819-26.

74. Liu YQ, Mu ZQ, You S, Tashiro S, Onodera S, Ikejima T. Fas/ FasL signaling allows extracelluar-signal regulated kinase to regulate cytochrome $\mathrm{c}$ release in oridonin-induced apoptotic U937 cells. Biol Pharm Bull. 2006;29(9):1873-9.

75. Liu YQ, You S, Tashiro S, Onodera S, Ikejima T. Oridonin induced U937 cell apoptosis through ERK pathway. Zhongguo Zhong yao za zhi $=$ Zhongguo zhongyao zazhi $=$ China $\mathrm{J}$ Chin Mater Med. 2005;30(23):1856-9.

76. Wang HJ, Li D, Yang FY, Tashiro S, Onodera S, Ikejima T. Oridonin induces human melanoma A375-S2 cell death partially through inhibiting insulin-like growth factor 1 receptor signaling. J Asian Nat Prod Res. 2008;10(7-8):787-98.

77. Zhang CL, Wu LJ, Tashiro S, Onodera S, Ikejima T. Oridonin induced A375-S2 cell apoptosis via bax-regulated caspase pathway activation, dependent on the cytochrome c/caspase-9 apoptosome. J Asian Nat Prod Res. 2004;6(2):127-38.

78. Chen S, Gao J, Halicka HD, Traganos F, Darzynkiewicz Z. Down-regulation of androgen-receptor and PSA by phytochemicals. Int J Oncol. 2008;32(2):405-11.

79. Cui Q, Tashiro S, Onodera S, Ikejima T. Augmentation of oridonin-induced apoptosis observed with reduced autophagy. J Pharmacol Sci. 2006;101(3):230-9.

80. Cui Q, Tashiro S, Onodera S, Ikejima T. Mechanism of downregulation of apoptosis by autophagy induced by oridonin in HeLa cells. Yao xue xue bao = Acta Pharm Sin. 2007;42(1): 35-9. 
81. Dai W, Zhang D, Duan C, Jia L, Wang Y, Feng F, Zhang Q. Preparation and characteristics of oridonin-loaded nanostructured lipid carriers as a controlled-release delivery system. J Microencapsul. 2010;27(3):234-41.

82. Huang J, Wu L, Tashiro S, Onodera S, Ikejima T. Bcl-2 upregulation and P-p53 down-regulation account for the low sensitivity of murine L929 fibrosarcoma cells to oridonin-induced apoptosis. Biol Pharm Bull. 2005;28(11):2068-74.

83. Kang N, Zhang JH, Qiu F, Tashiro S, Onodera S, Ikejima T. Inhibition of EGFR signaling augments oridonin-induced apoptosis in human laryngeal cancer cells via enhancing oxidative stress coincident with activation of both the intrinsic and extrinsic apoptotic pathways. Cancer Lett. 2010;294(2): $147-58$.

84. Kwan HY, Yang Z, Fong WF, Hu YM, Yu ZL, Hsiao WL. The anticancer effect of oridonin is mediated by fatty acid synthase suppression in human colorectal cancer cells. J Gastroenterol. 2013;48(2):182-92.

85. Li D, Wu LJ, Tashiro S, Onodera S, Ikejima T. Oridonin inhibited the tyrosine kinase activity and induced apoptosis in human epidermoid carcinoma A431 cells. Biol Pharm Bull. 2007;30(2):254-60.

86. Li RF, Wang QD. Regulation of telomerase activity and cell cycle of K562 cells by oridonin. Yao xue xue bao = Acta Pharm Sin. 2004;39(11):865-8.

87. Liu JJ, Wu XY, Lul HL, Pan XL, Peng J, Huang RW. Antiproliferation effect of oridonin on HL-60 cells and its mechanism. Chin Med Sci J = Chung-kuo i hsueh k'o hsueh tsa chih/ Chin Acad Med Sci. 2004;19(2):134-137.

88. Liu JJ, Wu XY, Peng J, Pan XL, Lu HL. Antiproliferation effects of oridonin on HL-60 cells. Ann Hematol. 2004;83(11): 691-5.

89. Bertelli AA, Ferrara F, Diana G, Fulgenzi A, Corsi M, Ponti W, Ferrero ME, Bertelli A. Resveratrol, a natural stilbene in grapes and wine, enhances intraphagocytosis in human promonocytes: a co-factor in antiinflammatory and anticancer chemopreventive activity. Int J Tissue React. 1999;21(4):93-104.

90. Sun KW, Ma YY, Guan TP, Xia YJ, Shao CM, Chen LG, Ren YJ, Yao HB, Yang Q, He XJ. Oridonin induces apoptosis in gastric cancer through Apaf-1, cytochrome c and caspase-3 signaling pathway. World J Gastroenterol. 2012;18(48): 7166-74.

91. Yi S, Chen Y, Wen L, Yang L, Cui G. Downregulation of nucleoporin 88 and 214 induced by oridonin may protect OCIM2 acute erythroleukemia cells from apoptosis through regulation of nucleocytoplasmic transport of NF-kappaB. Int J Mol Med. 2012;30(4):877-83.

92. Zhang Y, Wu Y, Tashiro S, Onodera S, Ikejima T. Involvement of PKC signal pathways in oridonin-induced autophagy in HeLa cells: a protective mechanism against apoptosis. Biochem Biophys Res Commun. 2009;378(2):273-8.

93. Zhou L, Sun L, Wu H, Zhang L, Chen M, Liu J, Zhong R. Oridonin ameliorates lupus-like symptoms of MRL(lpr/lpr) mice by inhibition of B-cell activating factor (BAFF). Eur J Pharmacol. 2013;715(1-3):230-7.

94. Bai N, He K, Zhou Z, Tsai ML, Zhang L, Quan Z, Shao X, Pan MH, Ho CT. Ent-kaurane diterpenoids from Rabdosia rubescens and their cytotoxic effects on human cancer cell lines. Planta Med. 2010;76(2):140-5.

95. Bai SP, Wei QY, Jin XL, Wu QX, Yang L. Two novel entkauranoid diterpenoids from Isodon japonica leaves. Planta Med. 2005;71(8):764-9.

96. He XJ, Wang HJ, Xia YJ, Ye ZY, Tao HQ. Empirical study of oridonin-induced gastric cancer cells MKN45 apoptosis.
Zhonghua wei chang wai ke za zhi $=$ Chin J Gastrointest Surg. 2009;12(6):607-10.

97. Kang N, Zhang JH, Qiu F, Chen S, Tashiro S, Onodera S, Ikejima $\mathrm{T}$. Induction of $\mathrm{G}(2) / \mathrm{M}$ phase arrest and apoptosis by oridonin in human laryngeal carcinoma cells. J Nat Prod. 2010;73(6):1058-63.

98. Ren KK, Wang HZ, Xie LP, Chen DW, Liu X, Sun J, Nie YC, Zhang RQ. The effects of oridonin on cell growth, cell cycle, cell migration and differentiation in melanoma cells. J Ethnopharmacol. 2006;103(2):176-80.

99. Gao YH, Wan ZX, Lai XW, Zhu Y, Li GY, Wu SH. Chemical constituents of Rabdosia nervosa (Hemsl) C.Y. Wu et H. W. Li. Zhongguo Zhong yao za zhi = Zhongguo zhongyao zazhi = China J Chin Mater Med. 1994;19(5):295-296, 320.

100. Satooka H, Isobe T, Nitoda T, Kubo I. Melanogenesis inhibitors from Rabdosia japonica. Phytomedicine. 2012;19(11):1016-23.

101. Han QB, Li RT, Li ML, Mou YK, Tian QE, Li SW, Sun HD. Ent-kauranoids from Isodon rubescens var. taihangensis. J Asian Nat Prod Res. 2005;7(1):31-6.

102. He F, Bai Y, Wang J, Wei J, Yu C, Li S, Yang W, Han C. Isolation and purification of oridonin from the whole plant of Isodon rubescens by high-speed counter-current chromatography. Molecules. 2011;16(9):7949-57.

103. Zhao AH, Xiang W, Na Z, Wang ZY, Lin ZW, Sun HD. Cytotoxic ent-kauranoids from Isodon leucophyllus. J Asian Nat Prod Res. 2004;6(2):145-50.

104. Que S, Zhao Y, Zhou Y, Zhang Q. Two en-kaurene diterpenoids from Tibetan medicine Caryopteris toroetii. Zhongguo Zhong yao za zhi $=$ Zhongguo zhongyao zazhi $=$ China $\mathrm{J}$ Chin Mater Med. 2009;34(12):1523-6.

105. Bao R, Shu Y, Wu X, Weng H, Ding Q, Cao Y, Li M, Mu J, Wu $\mathrm{W}$, Ding $\mathrm{Q}$, et al. Oridonin induces apoptosis and cell cycle arrest of gallbladder cancer cells via the mitochondrial pathway. BMC Cancer. 2014;14:217.

106. Chen JH, Wang SB, Li EM, Chen LM, Yuan SJ, Wang RL, Shen ZY. Inhibitory effect of Oridonin injection on heterotransplanted gastric adenocarcinoma in nude mice and its mechanism. Zhonghua zhong liu za zhi [Chinese journal of oncology]. 2008;30(2):89-92.

107. Bohanon FJ, Wang X, Ding C, Ding Y, Radhakrishnan GL, Rastellini C, Zhou J, Radhakrishnan RS. Oridonin inhibits hepatic stellate cell proliferation and fibrogenesis. J Surg Res. 2014;190(1):55-63.

108. Wang S, Zhang Y, Saas P, Wang H, Xu Y, Chen K, Zhong J, Yuan Y, Wang Y, Sun Y. Oridonin's therapeutic effect: suppressing Th1/Th17 simultaneously in a mouse model of Crohn's disease. J Gastroenterol Hepatol. 2015;30(3):504-12. doi:10. 1111 /jgh. 12710 .

109. Zhou X, Zhang X, Ye Y, Zhang T, Wang H, Ma Z, Wu B. Nanostructured lipid carriers used for oral delivery of oridonin: an effect of ligand modification on absorption. Int $\mathbf{J}$ Pharm. 2015;479(2):391-8. doi:10.1016/j.ijpharm.2014.12.068 (Epub 2014 Dec 30).

110. Gu Z, Wang X, Qi R, Wei L, Huo Y, Ma Y, Shi L, Chang Y, Li G, Zhou L. Oridonin induces apoptosis in uveal melanoma cells by upregulation of Bim and downregulation of fatty acid synthase. Biochem Biophys Res Commun. 2015;457(2):187-93. doi:10.1016/j.bbrc.2014.12.086 (Epub 2014 Dec 27).

111. Xu B, Shen W, Liu X, Zhang T, Ren J, Fan Y, Xu J. Oridonin inhibits BxPC-3 cell growth through cell apoptosis. Acta Biochim Biophys Sin (Shanghai). 2015;47(3):164-73. doi:10.1093/ abbs/gmu134 (Epub 2015 Feb 3). 